\title{
The Effect of Sleep Hygiene on The Sleep Quality in Elderly
}

\author{
Fitriana Kurniasari Solikhah, Nursalam, Elida Ulfiana \\ Master of Nursing \\ Faculty of Nursing, Universitas Airlangga \\ Surabaya, Indonesia \\ e-mail: fitriana.kurniasari.solikhah-2015@ fkp.unair.ac.id
}

\begin{abstract}
Most elderly has decreasing quality of sleep. Sleep patterns of elderly are different from children and adults, the need of the elderly to sleep is 5-7 hours / day. Elderly often awakened in the middle of the night because of physical changes due to age and disease patterns, sleep quality significantly decreases. A good sleep hygiene behavior is assumed can conduct a well sleep. The purpose of this study was to determine the effect of sleep hygiene on sleep quality in elderly. This study used quasi experiment with pre-test and post-test with control group. The research sample consisted of 14 respondents using purposive sampling technique. The statistical test used was simple linear regression to test the hypothesis and paired $t$-test, to analyze the difference average between the two paired samples (pre and post test). Sleep hygiene has a significant effect on the sleep quality in elderly. It had $p$ value $0.023<0.05$ with $F$-count $>$ F-table $(6.827>$ 4.45). Correlation of pre-test and post-test was 0.078. Sleep hygiene has an influence on the effect of sleep quality for the elderly.
\end{abstract}

\section{Keywords - elderly, sleep, sleep hygiene, and sleep quality}

\section{INTRODUCTION}

Old age is a natural phenomenon due to aging [1]. In the elderly, there is a variety of normal body function decline, causing various complications of diseases and problems. The greatest need for the elderly is a health level, to prosper. In handling policy for elderly, the government has issued Government Regulation No. 43 the year 2004 on the Implementation of Measures to Improve Welfare of Elderly, the law mandates, among others, carried out activities in a coordinated manner between the Government and the community to empower the elderly so that the elderly still be able to perform their social functions and relatively play an active role in the life [2].

One of the main aspects in improving elderly welfare is sleep maintenance to ensure recovery of body functions to the optimal levels and to ensure still awake during the day to accomplish all tasks and enjoy a high quality of life. Sleep is the current state of the recovery process for the body and the brain and is essential to the achievement of optimal health.
Rest and sleep are a basic need that must be met by everyone. Lack of sleep in the elderly can give effect to the physical, cognitive abilities and quality of life. The elderly who experience sleep disturbances will increase the amount of sleep during the daytime, in attention and memory problems, depression, is likely to fall during the night, and the low quality of life [3].

Their aging process makes the elderly more susceptible to sleep disturbances, in addition to lead normal changes in sleep patterns and break the elderly. Changes in normal sleep in the elderly is there is a decrease in NREM 3 and 4, the elderly hardly have stage 4 or sleeping in. Changes in sleep patterns elderly due to changes in physiological neurological system will decrease the number and size of neurons in the central nervous system. This resulted in the function of neurotransmitters in the neurologic system decreases, so that the distribution of nor-epinephrine which is a substance to induce sleep also decreases.

The results of the population census in 2010 showed that Indonesia is among the top five countries with the highest proportion of elderly people in the world, which reached 18.1 million people or 7.6 percent of the total population. The Central Bureau of Statistics (2013) projects, the number of elderly people $(60+)$ is expected to rise to 27.1 million in 2020, to 33.7 million in 2025 and 48.2 million in 2035[4]. Approximately $45 \%$ of the number of elderly in East Java reported having trouble of sleeping at night. There is $30 \%$ of the age group 70 years often waking at night. The increasing number of elderly poses a problem, especially in terms of health and well-being of the elderly. Elderly health problem that is often experienced is the presence of sleep disorders. Every year, about $20 \%-50 \%$ of adults report sleep disturbance and about $17 \%$ have a serious sleep disorder.

Sleep hygiene is a practice or habit that can affect sleep. Improvements sleep hygiene in the elderly is a simple but effective way to improve the quality of sleep. The behavior of good sleep hygiene can prevent the development of disorders and sleep problems. That means that good sleep hygiene behavior can help a person in having a good sleep quality as 
well. Sleep disorders and sleep during the day indicate that a person has bad sleep hygiene. Poor sleep hygiene behavior in the elderly, for example the elderly often spend more time in bed or asleep for a few moments during the day more awake at night [5]. Sleep hygiene is applied to the elderly in order to achieve REM of sleep, loss of muscle tension, increased cerebral activity (oxygen consumption, blood flow, and neural stimulation), the release of epinephrine, and $\beta$ waves that induce a feeling of relaxed or comfortable. When reached feeling relaxed and comfortable, the body will release a chemical derived from the pituitary gland that $\beta$ endorphin.

In planning the long-term efforts, the government must maintain and boost the quality of life of the elderly [6]. From the above background is expected by optimizing sleep hygiene methods will achieve a good sleep quality.

\section{METHOD}

This research was conducted in February to March 2017 at Griya UPT Wreda Surabaya, one of public nursing home in Surabaya. The study used quasy analysis experiment with the design of pre-test and post-test with control group. First, measurement of sleep quality were done early (pre-test) in all groups to determine the initial value before treatment (trials). In the following step, the treatment group was given an intervention (sleep hygiene), while the control group only do daily routine activity (no intervention). After the intervention was complete, the final measurement was done (post-test) in all groups.

The elderly was selected according to the inclusion criteria. Fourteen elderly that cooperative with researcher and able to write was recruited as respondent.

In order to analyze the research hypotheses, researcher was using linear regression whereas, the difference between paired sample (pre-test and post-test) using a paired t-test. Instrument for sleep quality was by using the Pittsburgh Sleep Quality Index (PSQI), with reliability score (Chronbach Alpha) was 0.87 , which meant reliable.

\section{RESULT}

Fourteen respondents obtained an increase in value of the sleep quality with an average value of 1.77. Result showed that sleep quality of 7 respondents in intervention group have increased significantly, from 7.57 at pre-test and to 9.14 at post-test, while in control group there was no difference between pre- and post-test. Therefore, there was the influence of sleep hygiene on the sleep quality of the elderly.

Good sleep hygiene behavior, including behavior in maintaining a regular sleep schedule can be applied to create a sleep schedule the beginning of sleep until wake up back written in the sleep diaries. The role of nurses was needed to explain how to fill out a sleep diary, which lasted for 30 days. Avoiding excessive sleep during the day implemented with activity on naps and keep physical activity such as gymnastics on 4-6 hours before bed at night, activities that can be done is light activity which is easily done by the elderly such as making crafts. Avoiding to go to bed in a state of hunger, thirst, or feeling of worry, reducing caffeine intake implemented that before sleep should consume snacks such as biscuits, avoid coffee and limiting alcohol intake, and focusing the mind when in bed in order to achieve optimal sleep quality.

Sleep hygiene has been defined as those behaviors that are believed to promote improved quantity and quality of sleep [7]. Research in other healthy adult populations shows that evening activity and conditions while falling sleep affect sleep quality [8][9]. Other sleep hygiene recommendations include decreasing schedule irregularity; night time exercise; and caffeine, alcohol, and tobacco use[7]. Activities in bed, such as reading or watching television, have also been associated with subjective measurements of poor sleep [9].

Table 1 showed the statistical test using simple linear regression show value of $\mathrm{R}$ (correlation value) is 0.602 . This value can be interpreted that the relationship between the two variables of the study is in a strong category. $\mathrm{R}$ square value was $36.3 \%$, which can be interpreted to mean that the independent variable $\mathrm{X} 1$ has an influence contributed $36.3 \%$ to variable $\mathrm{Y}$ and $63.7 \%$ are influenced by other factors beyond the variables X1. Significant value in the above table is $0.023<0.05$, which means a significant means of linear regression model meets the linearity criteria. The value of $\mathrm{F}$ count> F-table 6.827> 4.45 can be concluded that sleep hygiene variables affect simultaneously towards the elderly sleep quality variables. Linear regression equation is $\mathrm{Y}=$ $11.571+2,429 X$.

Table 2 showed p-value in the control group was 0.578 (> 0.05) means there was no difference in sleep quality between pre-test and post-test. While the p-value in the intervention group was $0.033(<0.05)$ means that there was difference in sleep quality between pre-test and post-test.

TABLE I. Statistical ResUlT

\begin{tabular}{|c|c|c|c|c|c|c|c|}
\hline \multirow[b]{2}{*}{ Model } & \multicolumn{2}{|c|}{$\begin{array}{l}\text { Unstandardized } \\
\text { Coefficients }\end{array}$} & $\begin{array}{l}\text { Standar. } \\
\text { Coeff. }\end{array}$ & \multirow[b]{2}{*}{ Sig. } & \multirow[b]{2}{*}{$\mathbf{R}$} & \multirow[b]{2}{*}{ R Square } & \multirow[b]{2}{*}{ F Count } \\
\hline & B & Std. Error & Beta & & & & \\
\hline $\begin{array}{l}\text { Constant } \\
\text { sleep hygiene }\end{array}$ & $\begin{array}{c}11.571 \\
2.429 \\
\end{array}$ & $\begin{array}{l}1.470 \\
0.929 \\
\end{array}$ & 0,602 & $\begin{array}{l}0.000 \\
0,023 \\
\end{array}$ & 0,602 & 0,363 & 6,827 \\
\hline
\end{tabular}

TABLE II. DIFFERENCES IN PRE AND POST TEST OF SLEEP QUALITY IN ELDERLY

\begin{tabular}{lccc}
\hline \multirow{2}{*}{ Group } & \multicolumn{3}{c}{ Mean SD } \\
\cline { 2 - 4 } & Pre Test & Post Test & p-value \\
\hline - Control & 6,1429 & 6,7143 & 0,578 \\
- Intervention & 7,5714 & 9,1429 & 0,033 \\
\hline
\end{tabular}




\section{DISCUSSION}

Frequent sleep disturbances and daytime sleepiness are the most telling signs of poor sleep hygiene. In addition, if elderly taking too long to fall asleep, elderly should consider evaluating sleep routine and revising bedtime habits. Just a few simple changes can make the difference between a good night's sleep and night spent tossing and turning [10].

According to reference [5], factors that affect a person's sleep hygiene, among others are sleep wake schedule, environment, diet, and medication use, as well as general matters include anxiety and physical activity during the day[5]. One of the most important sleep hygiene practices is to spend an appropriate amount of time asleep in bed, not too little or too excessive. Sleep needs vary across ages and are especially impacted by lifestyle and health[10].

The results are consistent with reference [11] which states that good sleep hygiene practices related to good sleep. This study shows that applying the elderly sleep hygiene for 30 days in accordance with the existing guideline influence the improvement of sleep quality fulfillment elderly meaningfully. While the elderly who do not apply sleep hygiene show that there is no increased fulfillment sleep quality in the elderly. Guideline of sleep hygiene which will be applied include: go to bed and get up at the same time every day, avoid naps during the day, practice every day ( \pm 4-6 hours before bedtime), avoid large meal before bed, go somewhere sleep only to rest or sleep, do not have a clock in view of the bed when lying down (in line with the view at the time of sleeping position), reduce external noise as much as possible when trying to sleep (use ear plugs are allowed), reduce the use of stimulants such as caffeine or nicotine, prepare to sleep half an hour before lying down to sleep, and if the mind is not focused when lying down, make thinking about the memories, when life was good and quiet.

According to reference [8], the elderly is less knowledgeable about the health of sleep related to the sleep practice. Elderly biologically needs 7 hours of sleep per night, but no later than the elderly asleep around $1 \mathrm{pm}$ was due to socio-cultural factors, the environment[10]. The success of this research is affected by the implementation of the sleep hygiene done by respondents as taught by researcher. The first implementation on a trial basis for one week showed that the implementation of sleep hygiene done by respondents on the first day is not in accordance with 10 points on guideline, but in the implementation of the second day onwards with the guidance of researcher and assisted nursing homes, the implementation of sleep hygiene can work as expected.

\section{CONCLUSION AND RECOMMENDATION}

\section{A. Conclusion}

There is an influence between the application of sleep hygiene on the quality of sleep of elderly in UPT Griya Wreda Surabaya. Elderly cooperative, physical health of the elderly and support system (nursing homes) should be considered because it has associated with the implementation of 10 points guideline of sleep hygiene to achieve optimal sleep quality in the elderly in a nursing home.

\section{B. Recommendation}

Sleep hygiene can be applied to a person who has poor sleep quality. Limiting strenuous activity before sleep may useful for elderly to enter sleeping. Efectivity of the sleep hygiene depends on the implementation of 10 points with existing standards.

\section{REFERENCES}

[1] S. K. Mathur, "Allergy and asthma in the elderly.," Semin. Respir. Crit. Care Med., vol. 31, no. 5, pp. 587-95, Oct. 2010.

[2] Menteri Kesehatan Republik Indonesia, "Peraturan Menteri Kesehatan Republik Indonesia Nomor 79 Tahun 2014 tentang Penyelenggaran Pelayanan Geriatri di Rumah Sakit.” Kementerian Kesehatan Republik Indonesia, Jakarta, 2014.

[3] Mental Health Foundation, "Sleep Matters The impact of sleep on health and wellbeing Mental Health Awareness Week 2011." Mental Health Foundation, London.

[4] Menteri Kesehatan Republik Indonesia, "Peraturan Menteri Kesehatan Republik Indonesia Nomor 25 Tahun 2016 Tentang Rencana Aksi Nasional Kesehatan Lanjut Usia Tahun 2016-2019.” Kementerian Kesehatan Republik Indonesia, Jakarta, 2016.

[5] N. Amir, "Gangguan Tidur pada Lanjut Usia: Diagnosis dan Penatalaksanaan," Cermin Dunia Kedokt., no. 157, pp. 196-206, 2007.

[6] M. L. Marais, D. Marais, and D. Labadarios, "Assessment of nutritional status of older people in homes for the aged in the Somerset West area," South African J. Clin. Nutr., vol. 20, no. 3, pp. 102-108, 2007.

[7] E. J. Stepanski and J. K. Wyatt, "Use of sleep hygiene in the treatment of insomnia.," Sleep Med. Rev., vol. 7, no. 3, pp. 215-25, Jun. 2003.

[8] F. C. Brown, W. C. Buboltz, and B. Soper, "Relationship of Sleep Hygiene Awareness, Sleep Hygiene Practices, and Sleep Quality in University Students," Behav. Med., vol. 28, no. 1, pp. 33-38, Jan. 2002.

[9] D. F. Mastin, J. Bryson, and R. Corwyn, "Assessment of Sleep Hygiene Using the Sleep Hygiene Index," J. Behav. Med., vol. 29, no. 3, pp. 223 227, Jun. 2006.

[10] National Sleep Foundation, "How Much Sleep Do We Really Need? National Sleep Foundation," 2017. [Online]. Available https://sleepfoundation.org/how-sleep-works/how-much-sleep-do-wereally-need. [Accessed: 28-Jul-2017].

[11] J. A. Mindell, L. J. Meltzer, M. A. Carskadon, and R. D. Chervin, "Developmental aspects of sleep hygiene: Findings from the 2004 National Sleep Foundation Sleep in America Poll," Sleep Med., vol. 10, no. 7, pp. 771-779, Aug. 2009. 